اثر استخدام منهاج تدريبي مقترح في تطوير بعض المتطلبات الخاصة ومستوى الأداء المهاري في الحركات الأرضية للناشئين

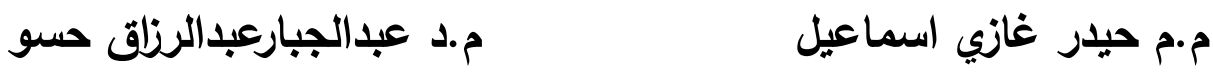

جامعة الموصل / كلية التربية الرياضية

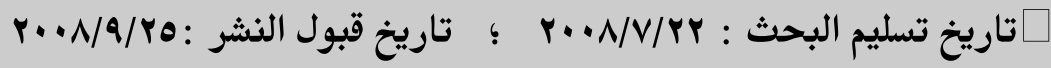

الملخص

هذف البحث الى التعرف على ما يأتي:-

ا. اثر المنهاج التدريبي المقترح في تطوير بعض المتطلبات الخاصة ومستوى الأداء المهاري في الحركات الأرضية للناششئ. r. الفروق في بعض المتطلبات الخاصة ومستوى الأداء المهاري بين الاختبارين القبلي والبعدي لكل من المجموعتين التجريبية والضابطة . r. الفروق في بعض المتطلبـات الخاصـة ومستوى الأداء المهاري في الاختبـار ألبعدي بين المجموعنين التجريبية والضابطة . وافترض الباحثان ما يأتي:-

1. اوجود فروق ذات دلالة معنوية في بعض المتطلبات الخاصة ومستوى الأداء المهاري بين

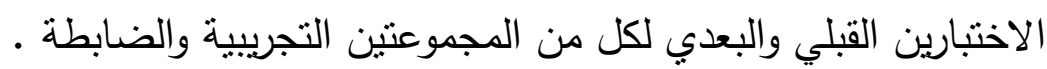

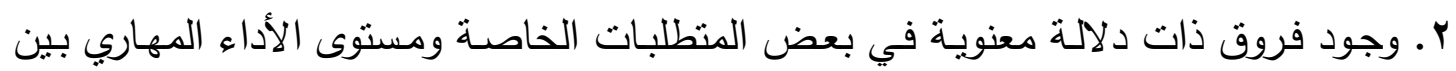
المجموعنين التجريبية والضابطة في الاختبار ألبعدي في الحركات الأرضية. واستنتج الباحثان مايأتي: - احدث المنهاج التدريبي المقترح المستخدم من قبل المجموعة التجريبية نطوراً في معظم

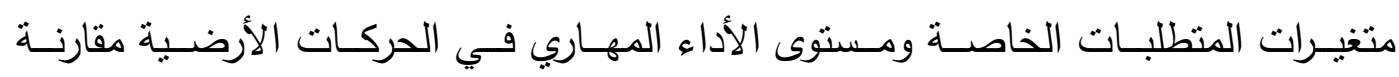
بالمجموعة الضابطة. - - لـم يحرز المنهاج التقليدي الذب استخدمته المجموعـة الضابطة أي تقدم في المنطلبـات الخاصة قبد البحث ومستوى الأداء المهاري في الحركات الأرضية. 


\section{ABSTRACT \\ effects of using a suggested training program on the developing the speciliz requirements and skill performance of the floor exercise for juniors Gymnastics \\ Assist Lecturer Haider K.Ismail \\ Lecturer.Dr. Abdul Jabbar A.Hasso \\ University of Mosul / college of physical education}

\section{* The present research aims at investigating the following:}

1.The effect of the suggested training program on developing the speciliz requirements and skill performance of the floor exercise.

2. The differences concerning some items of the speciliz requirements and skill performance between pre and post tests for each of experimental and control groups.

3. The difference concerning some items of the speciliz requirements and skill performance for the post tests between the experimental and control groups. hypothesi:

1. There are significant differences in the speciliz requirements and skill performance between the pre and post tests of the two groups.

2. There are significant differences between the experimental and control groups in the post test for the specializ requirements and skill performance.

\section{Conclusion: Results indicate the Following:}

1.The suggested program used by experimental group had improvedThe most speciliz demauds and skill performance of floor exercise campard with the control group program has excelled in most speciliz requirements in addition to the skill performance for the two groups.

2. The tradition program used by the control group had not any improvment in the speciliz demards in gueshon and skilfull performance of floor exercise

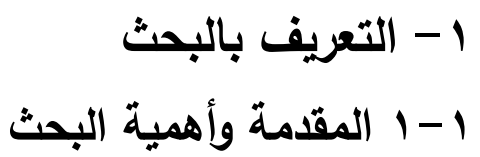

يعد تحقيق الانجازات الرباضية المتميزة هدفاً تسعى البهه جميع الدول، اذ أصبحت هذه

الانجازات دليلا على رقي الثعوب وتقدمها، فانطلق عالم اليوم بخطوات واسعة في مجال النشاط

الرياضي، وتعد رياضـة الجمناسنك من ابرز الأنشطة الرياضية التي وصل فيها مستوى الأداء

اللاعبين إلى حد الخيال فحصل أكثر من لاعب على درجات عالية في أكثر من جهاز ، ويشير

(علي) " ان النشاطات الرياضية تختلف من حيث طبيعة الأداء والجهد المبذول والوسط الذي 


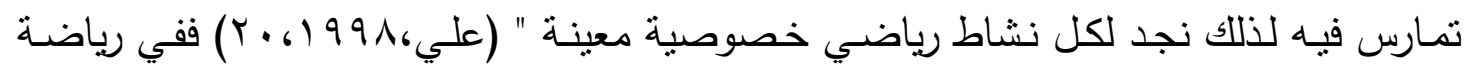

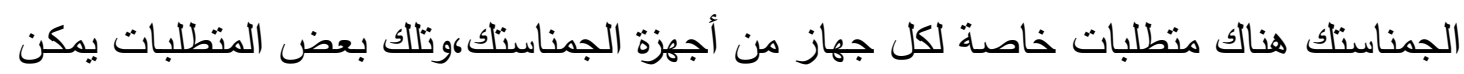
ملاحظتها بصورة واضحة لدى اللاعبين ذوب المستوى المتقدمهوقد كثفت أبحاث كثيرةعن أهمية الهنية

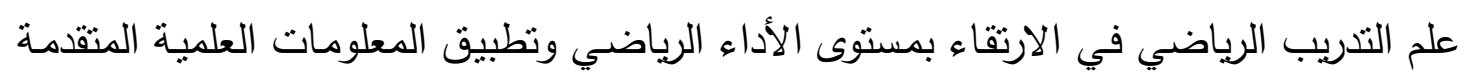

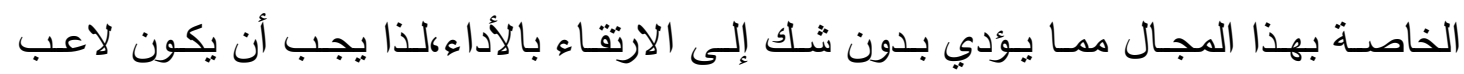

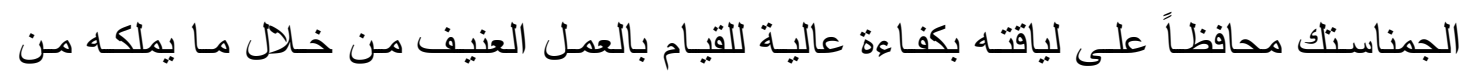

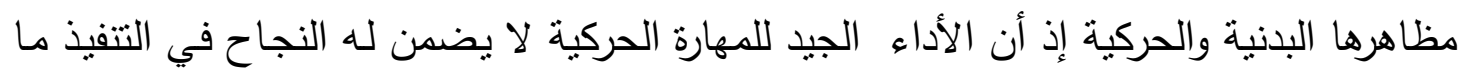

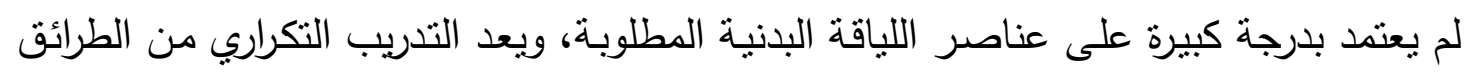
المهمة والأساسية في التدريب الرياضي ولاسيما في المسابقات التي تعتمد على الطاقة اللاهوائية

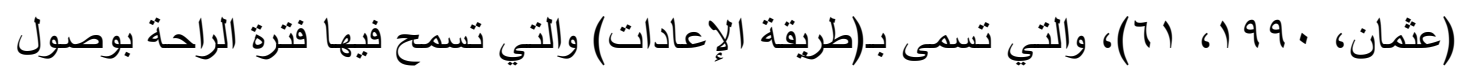

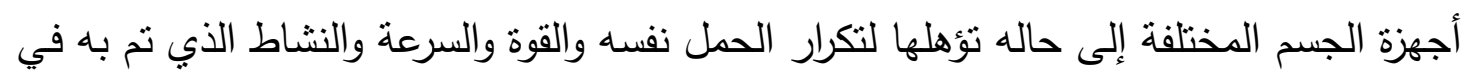

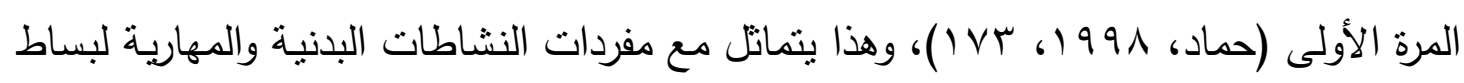

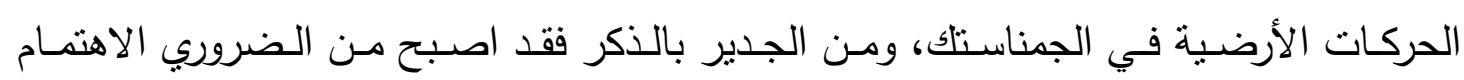

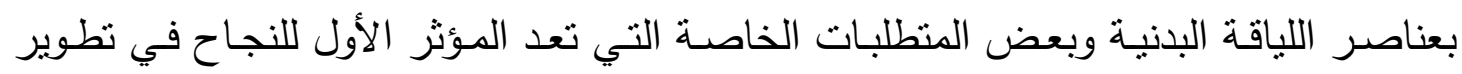

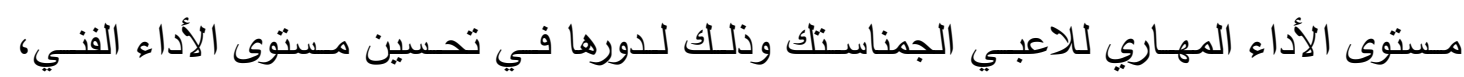
فرياضة الجمناستك تحتاج الى الكثير من الصفات البدنية الخاصة والعامة التي تساعد اللاعب التباء

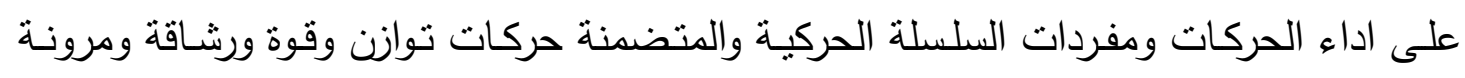

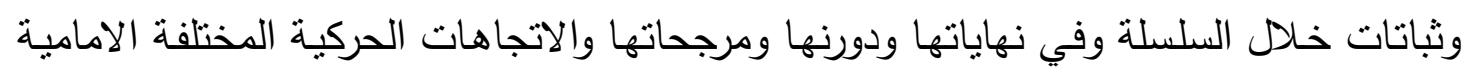
والخلفية والجانبية مع اداء اللف حول المحاور المختلفة، مما حدا بالباحثنان الى تصميم منهاج تدريبي مقترح يعمل على تطوير بعض المتطلبات الخاصة في الحركات الأرضية لدى الناشئين

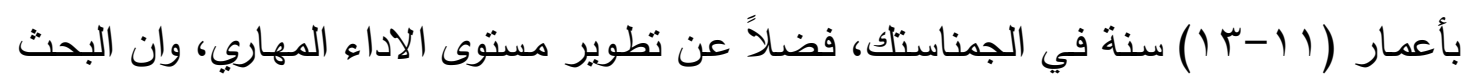

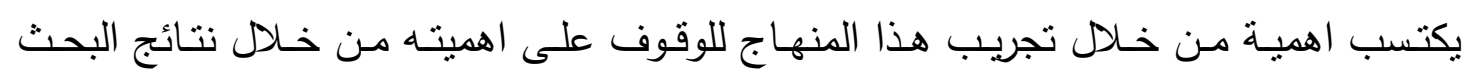
والاستفادة منه في العملية التدريبية.

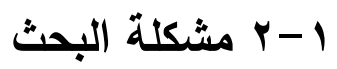
تحتاج رياضة الجمناستلك من اللاعب ان يكون في قمة حالته المتوازنة في اثثاء الثروع

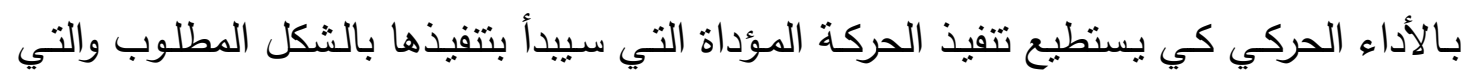

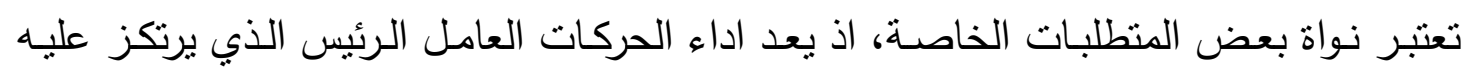

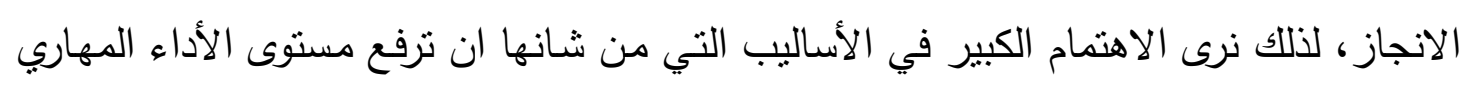

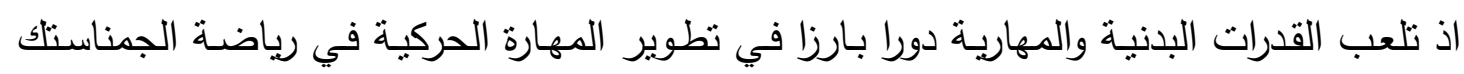


مما دفح الباحثان نحو بنـاء منهاج تدريبي مقترح في تطوير بعض المنطلبـات الخاصـة في الحركات الأرضية.

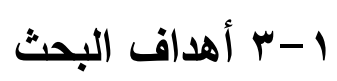

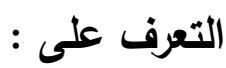

1-ب-1 اثر المنهاج التدريبي المقترح في تطوير بعض المنطلبـات الخاصـة في الحركات الأرضية.

1-r-r الفروق في بعض المتطلبات الخاصـة ومستوى الأداء المهاري بين الاختبارين القبلي

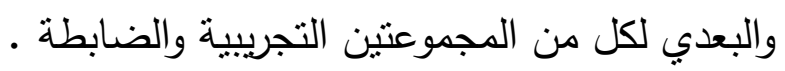
1-r-r الفروق في بعض المنطلبات الخاصة ومستوى الأداء المهاري في الاختبار ألبعدي بين الجين المجموعتين التجريبية والضابطة . 11-ـ - إوجود فروق ذات دلالة معنوية في بعض المتطلبات الخاصة ومستوى الأداء المهاري بين الاختبارين القبلي والبعدي لكل من المجموعنين التجريبية والضابطة.

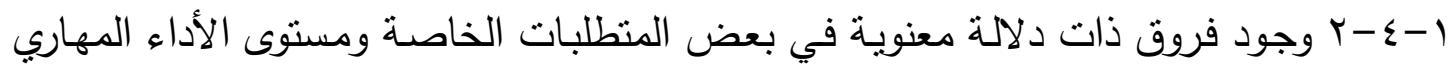
في الحركات الأرضية بين المجموعتن التجريبية والضابطة في الاختبار البعدي. 1-0 مجالات البحث

1-1 - المجال البشري : لاعبو منتخب محافظة نينوى بأعمار (11-1 (1) سنة .

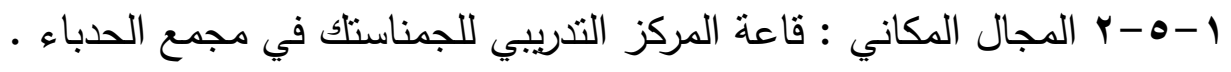

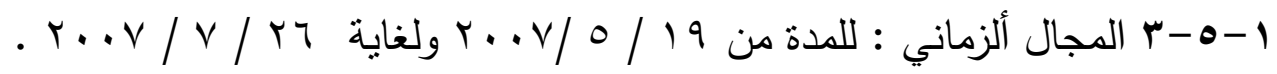
1-7 المصطلحات 1- 1- 1-1 المتطلبات الخاصة:

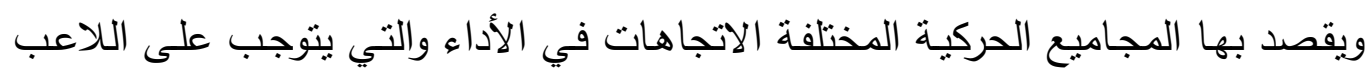

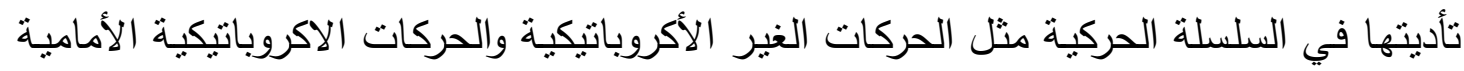

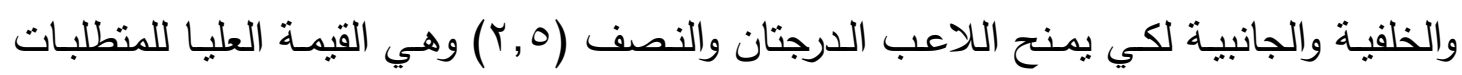

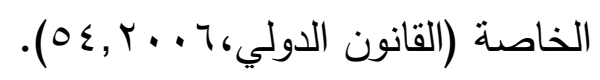

r - ب الإطار النظري والدراسات المشابهة

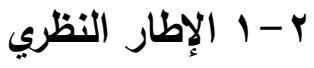


ץ-1 - الأعداد المهاري في وحدة ( جرعة التدريب)

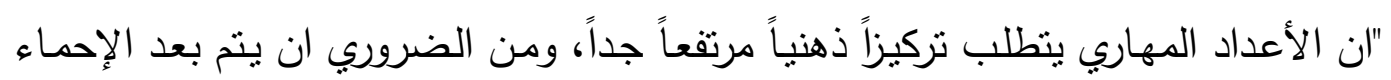

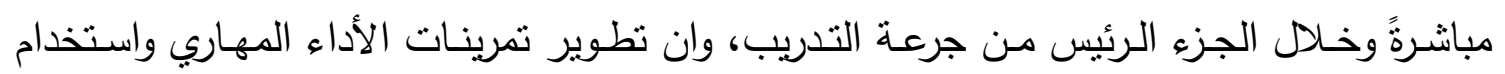

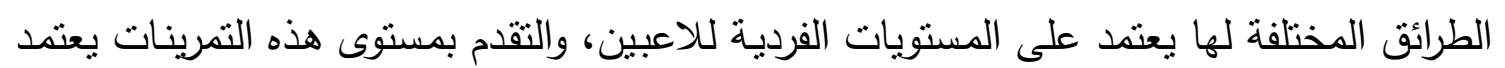

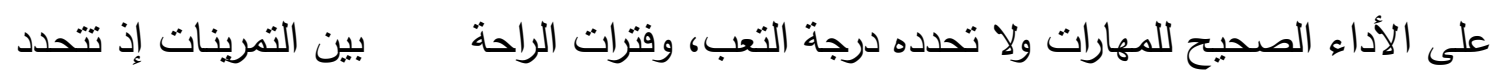
فردياً طبقاً لما يحققه اللاعب من تقدم في الأداء المهاري".

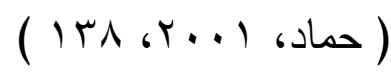

r r- r r الجمناستك ومرحلة الناشئين

لاثك أن أهداف تدريب النانشئين تكمن في الأعداد المنظم لإمكان الوصول إنى إلى المستويات

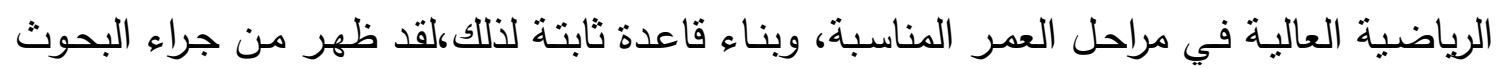

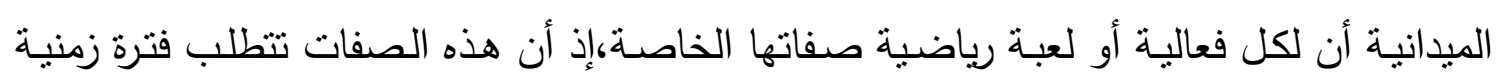
للتدريب تتتاسب مع المستوى الرياضي، وبذللك يتحدد طول الفترة الزمنية اللازمة لتدريب الناشئين

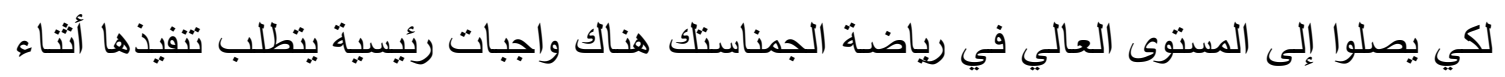

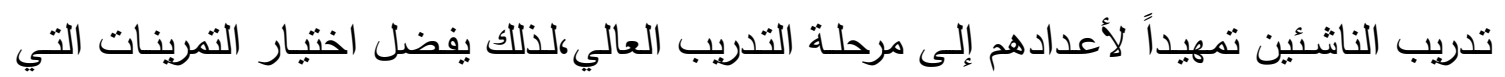

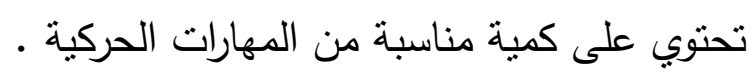
r-r - r الحركات الأرضية

وهي نلاك الحركات المتتاسقة والإيقاعية المنسجمة المتضمنة حركات التوازن والثبات والقوة

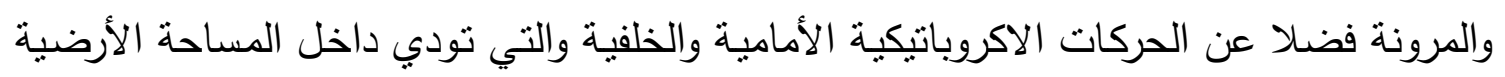

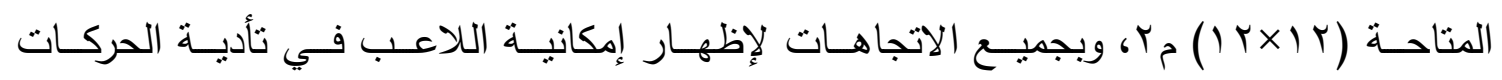

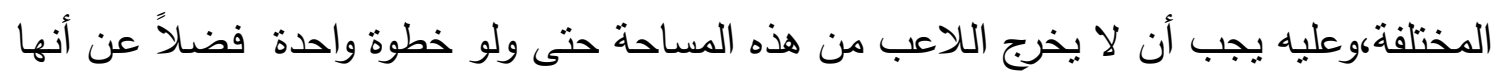

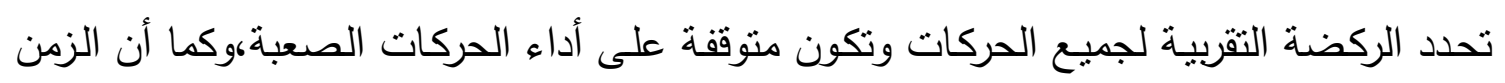

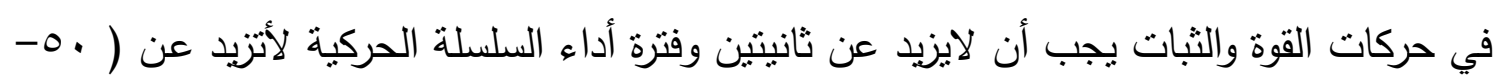

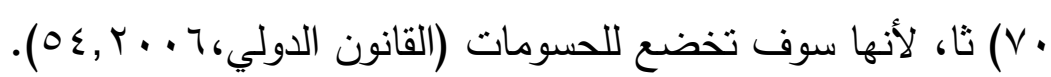

$$
\begin{aligned}
& \text { r- }
\end{aligned}
$$

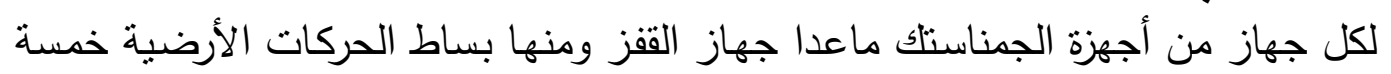

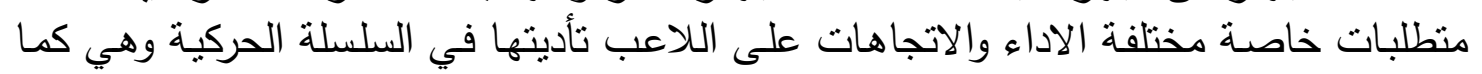

$$
\begin{aligned}
& \text { يأتي : } \\
& \text { - أجزاء نوازن وقوة ومرونة }
\end{aligned}
$$

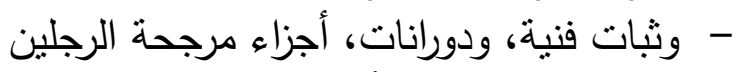

$$
\begin{aligned}
& \text { - حركات اكروباتيكية أمامية أنزاء } \\
& \text { - حركات اكروباتيكية خلفية اكنية } \\
& \text { - حركات اكروباتيكية جانبية أو الوثبات الخلفية مع نصف لفة. }
\end{aligned}
$$




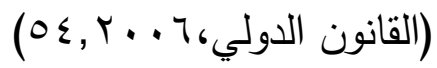

Y V- - تقويم السلسلة الحركية في بساط الحركات الأرضية

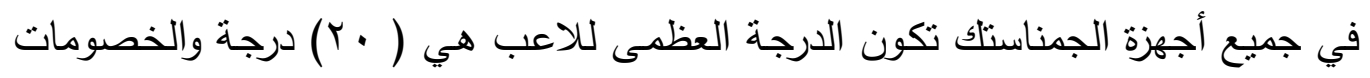

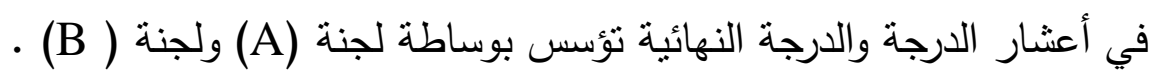

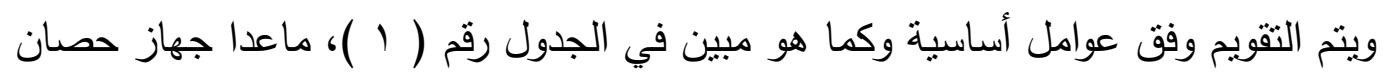
القزز غير مشمول بهذه العوامل.

(1) الجدول رقم (1)

يبين العوامل الأساسية في التقويم

\begin{tabular}{|c|c|c|c|}
\hline لجنة التقويم & قيمة العامل & العوامل الأساسية & $ت$ \\
\hline A & حسب صعوبة الحركات & درجة الصعوبة & 1 \\
\hline A & $r_{6} 0$ & بعض المتطلبات الخاصة & $r$ \\
\hline A & حسب ربط الحركات & النقاط التشجيعية & $r$ \\
\hline $\mathrm{B}$ & عشرة درجات . ., • & الأداء الفني & $\varepsilon$ \\
\hline درجة & $r \cdot, \ldots$ & المجموع الكلي & \\
\hline
\end{tabular}

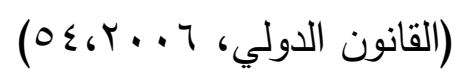

r r r r الدراسات المشابهة

قام الباحثانان بالاطلاع على العديد من الدراسات المشابهة التي تتاولت عدة جوانب من

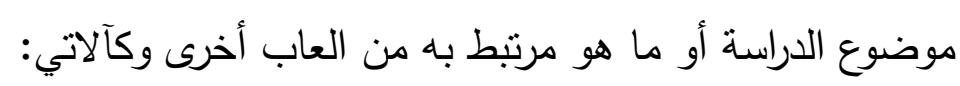

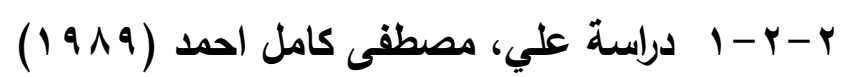

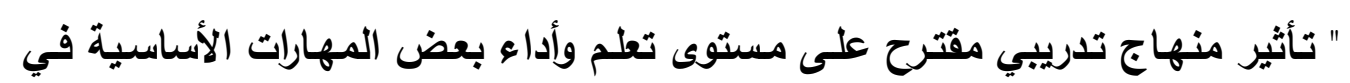

التمرينات الأرضية " ماتير

هدفت الدراسـة التعرف على:مدى فاعلية المنهاج التدريبي المقترح في تعلم وتحسين

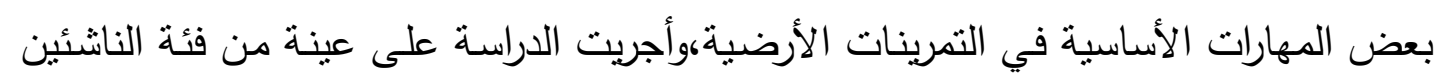

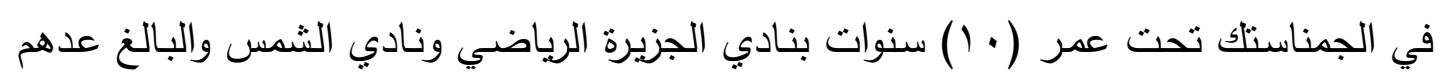

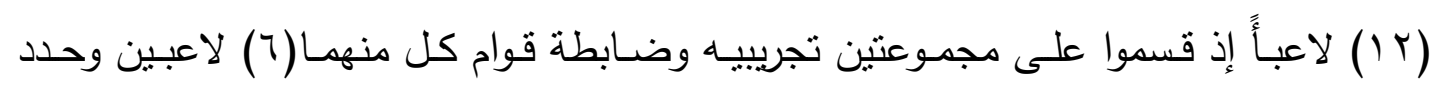

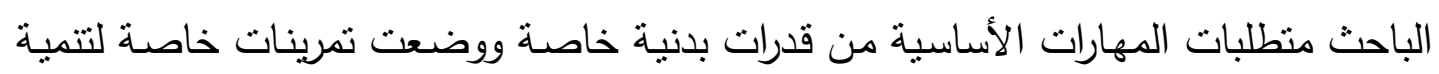

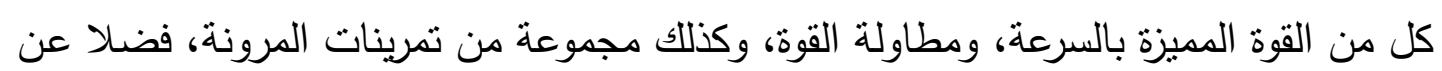
تمرينات الأعداد المهاري. - واستغرق المنهاج التدريبي المقترح أربعـة اثـهر وبواقع (0) وحدات تدريبيـة في الأسبوع

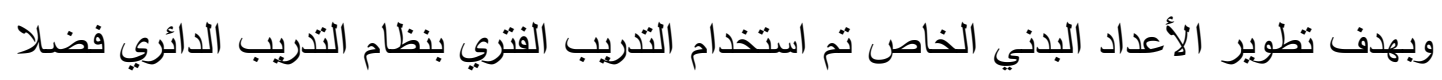
عن تطوير الأعداد المهاري.وأسفرت النتائج كما يأني: 
- أن أساليب الأعداد البدني المستخدمة لدنهاج التنريب الفنري بنظام التنريب الدائري قد أدت

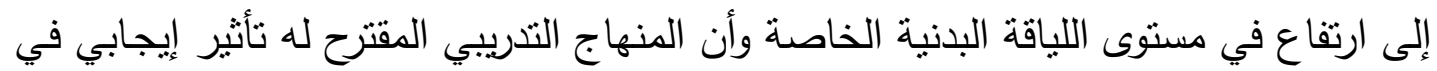

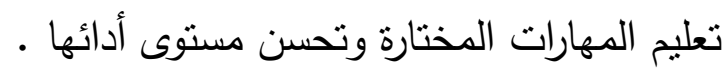

r-r - r دراسة مصطفى، علاء الدين حامد، (99 99 (1) " تأثير تنميـة القوة العضلية النسبية والمرونـة لمفاصل كل من الذراعين والثرجلين والعمود الفقري على مستوى أداء سلسلة اكروياتيكية خلفية على بساط الحركات الارضية في في فئه

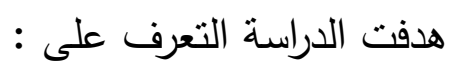

- - تأثير تتمية القوة العضلية النسبية والمرونة لمفاصل كل من الذراعين والرجلين والعمود الفقري على مستوى اداء القلبة الجانبية والمنحنية مـع ربع لفة المنبوعة بالقلبة الخلفية على اليدين

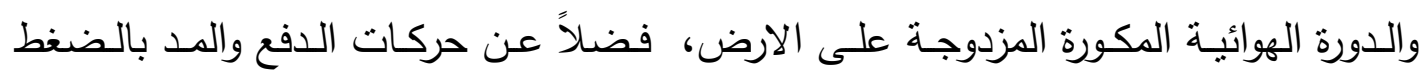
للذراعين في أداء السلسلة الاكروباتيكية .

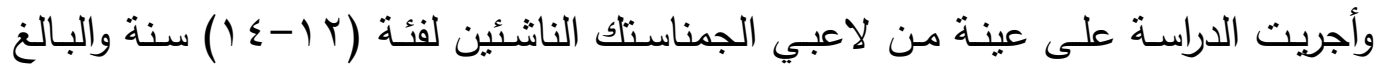
عددهم (^) لاعبين مستخدماً التصميم التجريبي للقياس (القبلي والبعدي ) للمجموعة التجريبية

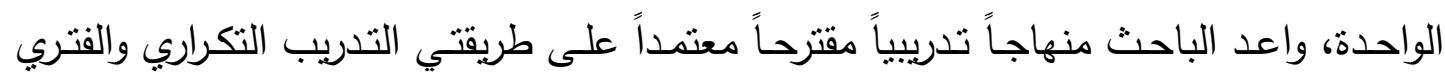
بنوعية (المنذفض والمرتفع الشدة) وباستخدام النظام الدائري، واشتمل المنهاج على تمرينات

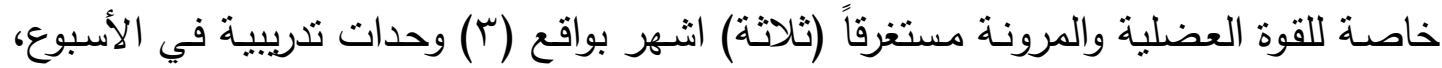

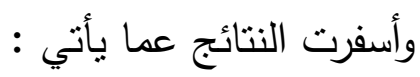
- ان مرونـة العمود الفقري ومطاطية العضلات خلف الفخذين لهما تأثير إيجابي على تحسن مفاصل الكتقين والذراعين والفذذين فضلاً عن تأثيرها في مستوى اداء القلبة الجانبية والمنحنية مع ربع لفة والدورة الهوائية المكورة والمزدوجة على بساط الحركات الارضية .

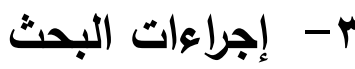

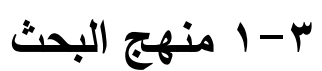

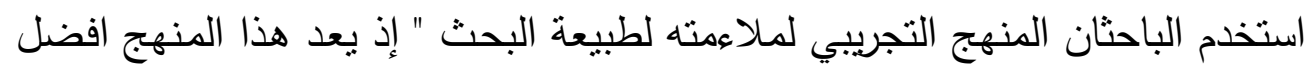

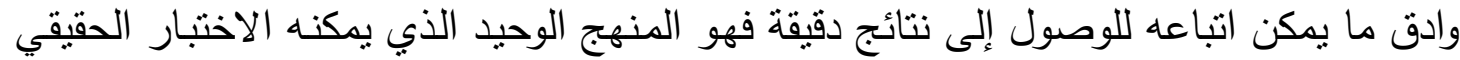

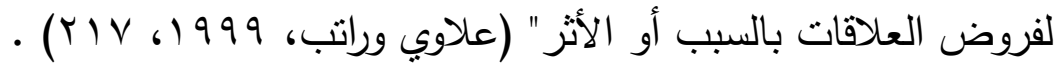

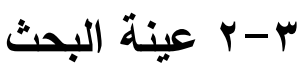

تم اختيار عينة البحث من لاعبي منتخب محافظة البنة نينوى بالجمناستك لفئة الناشئين بأعمار

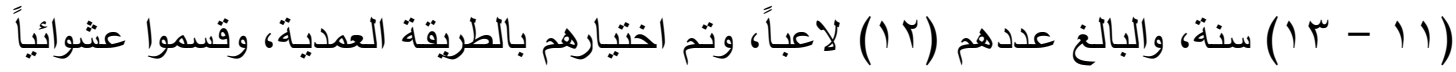


باستخدام القرعة، وبعد القرعة وضعوا اصحاب الارقام الفردية في المجموعة التجريبية والأرقام

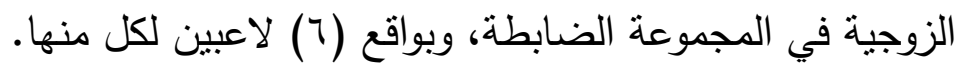

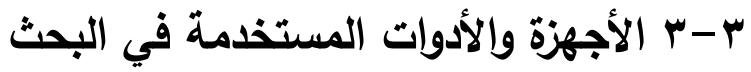

$$
\text { - شاعة توقيط قياس عدد (1) - (1) }
$$

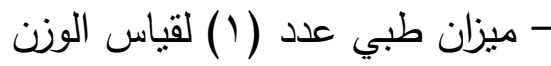

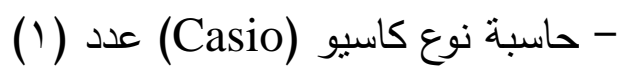

$$
\begin{aligned}
& \text { - استمارة جمع المعلومات } \\
& \text { r - ع وسائل جمع البيانات } \\
& \text { - الاختبارات والمقاييس } \\
& \text { - الاستبيان. } \\
& \text { r - الاختبارات }
\end{aligned}
$$

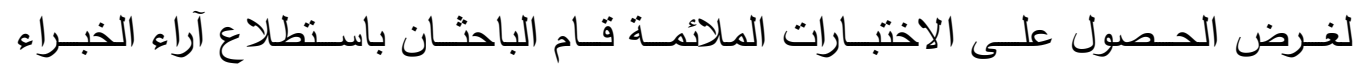
والمتخصصين في مجالات العلوم الرياضية المختلفة وقد تم توزيع استمارات استبيان على السادة

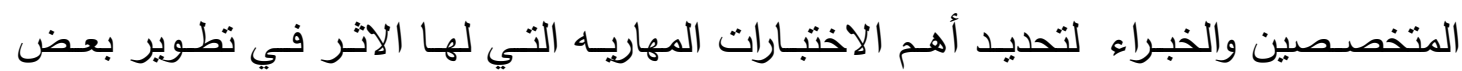

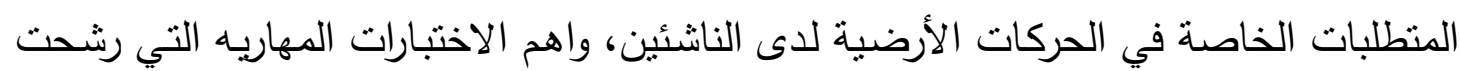
حسب اتفاق اغلب المتخصصين هي :- مجموعة الحركات غير الاكروباتيكية منل الوقوف على اليدين بالضغط من الارتكاز الزاوي

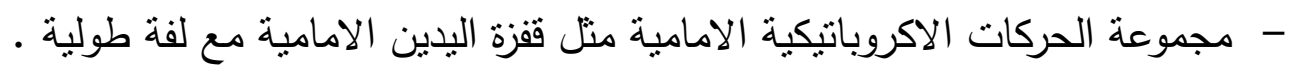

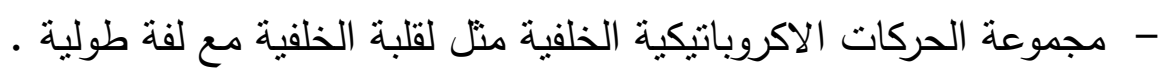

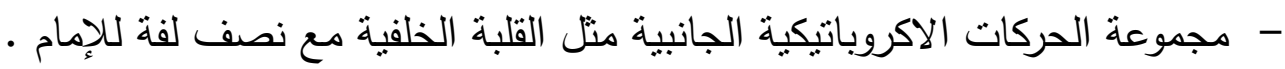

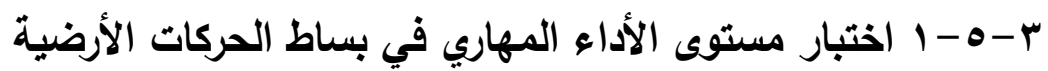

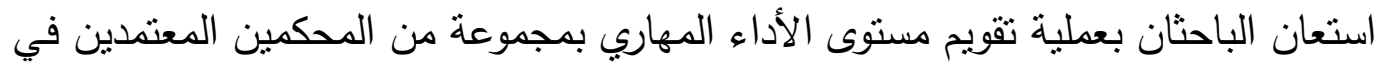

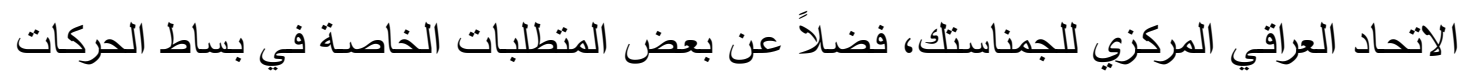

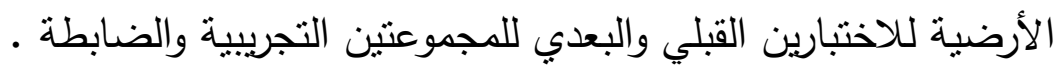
r- r- r التجرية الاستطلاعية للاختبارات

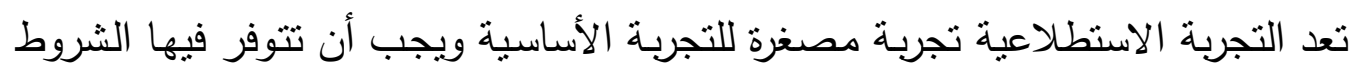

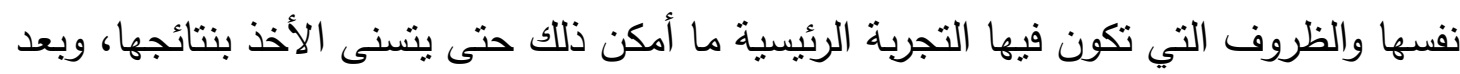

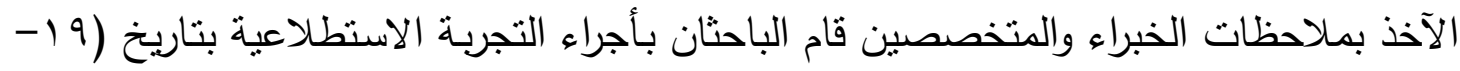

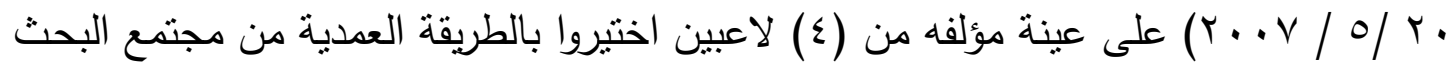

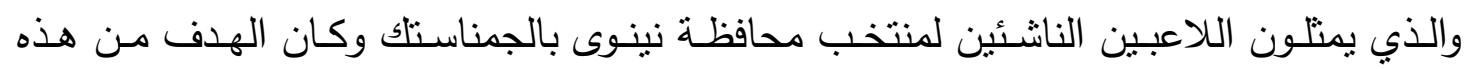
التجربة التعرف على الصعوبات والمشاكل التي تواجه الباحثان أثناء تتفيذ الاختبارات لأفراد عينة التانة البحث وقد قام الباحثان بتقسيم الاختبارات على مدى يومين، 


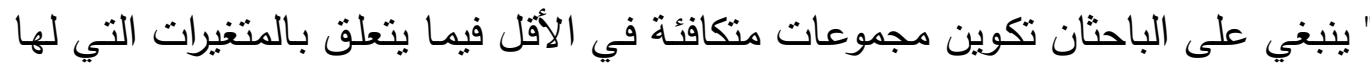

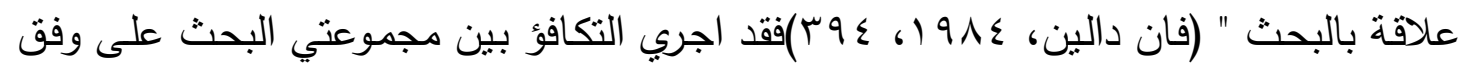

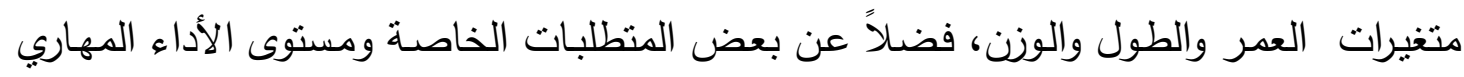

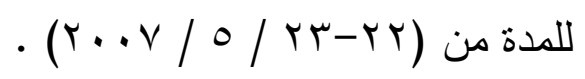

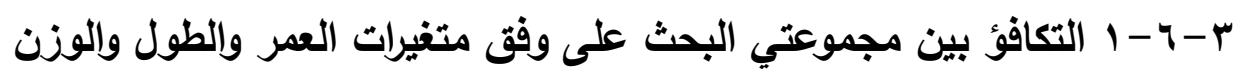

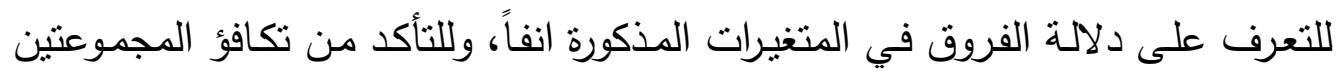

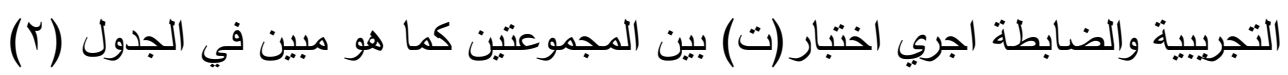

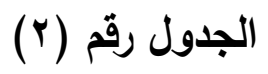

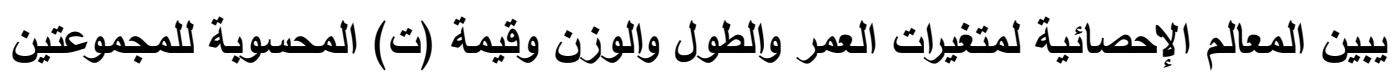

\begin{tabular}{|c|c|c|c|c|c|c|c|}
\hline \multirow{2}{*}{ النتيجة } & \multirow{2}{*}{ قالمحسوية (ت) } & \multicolumn{2}{|c|}{ المجموعة الضابطة } & \multicolumn{2}{|c|}{ المجموعة التجريبية } & \multirow{2}{*}{ وحدة القياس } & \multirow{2}{*}{ المتغيرات الإحصائية } \\
\hline & & $\varepsilon^{ \pm}$ & س- & $\varepsilon^{ \pm}$ & س- & & \\
\hline غير مغنوي & $r, 1$. & $1, \varepsilon 1$ & $1 \leq \varepsilon$ & 1,01 & $1 \leq 7$ & لالقرب شهر & 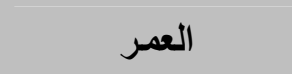 \\
\hline غير معنوي & $1, .0$ & 1 & $1, r \wedge$ & I,AV & $I T V$ & سنتيمتر & الطول \\
\hline غير معنوي & 1,11 & 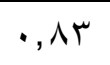 & $r q, r$. & $1, \vee \wedge$ & $r \cdot, \lambda$. & كيلو غرام & الوزن \\
\hline
\end{tabular}
التجريبية والضابطة

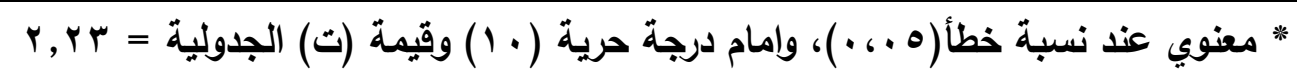

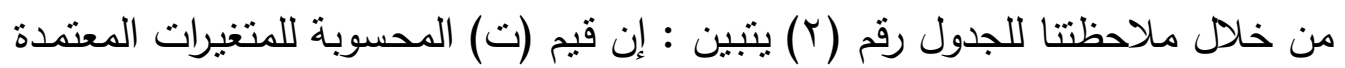

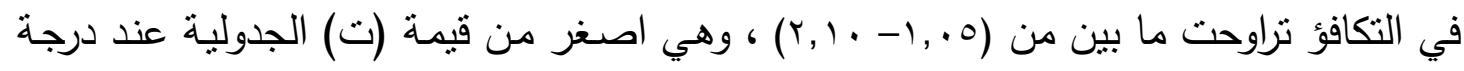

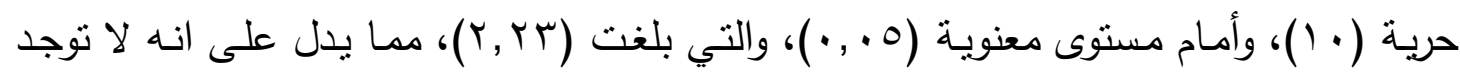

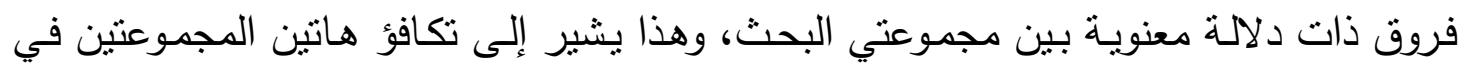
متغيرات العمر والطول والوزن.

r-

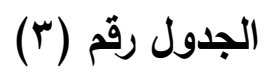

يبين المعالم الإحصائية لمستوى أداء بعض المتطلبات الخاصة والأداء المهاري وقيمة (ت) المحسوية للمجموعتين التجريبية والضابطة 


\begin{tabular}{|c|c|c|c|c|c|c|c|}
\hline \multirow{2}{*}{ النتيجة } & \multirow{2}{*}{ قالمحسوية (ت) } & \multicolumn{2}{|c|}{ المجموعة الضابطة } & \multicolumn{2}{|c|}{ المجموعة التجريبية } & \multirow{2}{*}{ القياس } & \multirow{2}{*}{ المتغيرات لمعالم الإحصائية } \\
\hline & & $\varepsilon \pm$ & س- س & $\varepsilon^{ \pm}$ & س- - & & \\
\hline غير معنوي & 1,17 & $\cdot, r r$ & 1,17 & $\cdot, r \cdot$ & $1, r r$ & درجة & بعض المتطلبات \\
\hline غير معنوي & $1, \leqslant V$ & $\cdot, 1 \pi$ & $1 \cdot, 1$ & $\cdot, \curlyvee \wedge$ & $11, \cdot 1$ & درجة & مستوى الأداء المهاري \\
\hline
\end{tabular}

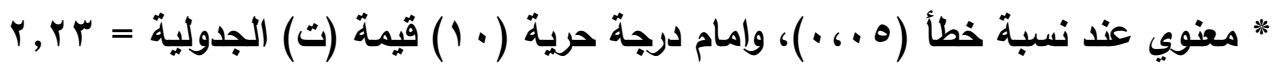

يتبـين مـن الجدول رقم (r) : أن قيم (ت) المحسوبة في متغيرات بعض المتطلبـات

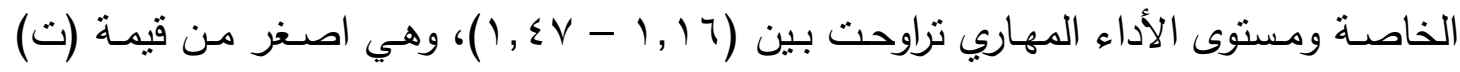

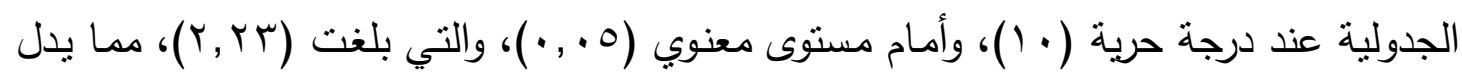
على انـه لا توجد فـروق ذات دلالـة معنويـة بـين مجموعتي البحث، وهذا يشير إلى تجـانس

• (1) - داتين المجموعتين ب-V المنهاج التدريبي

قام الباحثان بتصميم نموذج من المنهاج التدريبي المقترح وتم توزيعه على مجموعة من المتخصصين والخبراء والأخذ بـآرائهم وهو معد لتطوير بعض المتطلبـات الخاصسة مستخدما طربقة التدربب التكراري،واستغرق تتفيذ المنهاج (^) أسابيع، ونفذ من قبل المدربين المعتمدين في دهوي الاتحادين العراقي والفرعي للجمناستك. ب-1 التجربة الرئيسة للبحث: ب-1 - الاختبارات القبلية

اجرى الباحثان جميع الاختبارات المعتمدة في البحث للمجموعتين التجريبية والضابطة. r-N-r تثفيذ المنهاج التدريبي

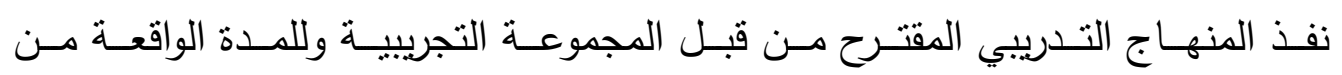

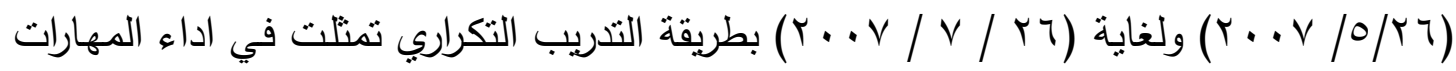
الحركية معتمدة في بنائها على بعض المتطلبات الخاصة في الحركات الأرضية لتتمية الاعدادين البدني والمهاري، فضلاً عن تتمية وتحسين القدرات الحركية وتثبيتها للإعداد المهاري في طريقة التدربب التكراري، بينما استخدمت المجموعة الضابطة المنهاج المعد من قبل المدرب، وباستخدام عشوائي للزمن، وعدد التمـارين دون اللجوء الى نظـام تدريب منبع، ولكنه جاء ممـاثلا لجميع الوحـدات التدريبيـة، إذ تراوح الزمن مابيـن ( • (- ع) دقيقة على بساط الحركات الأرضية ،

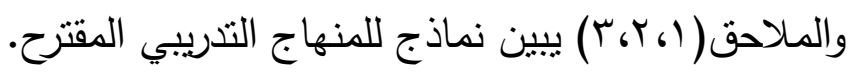
r-N- 
بعد الانتهاء من تتفيذ المنهاج التدريبي المقترح قام الباحثان بأجراء الاختبارات البعدية

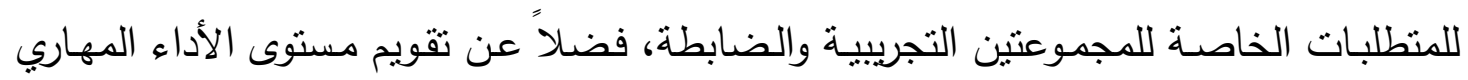
الذي حددت فيه بعض المتطلبات الخاصـة وفقا لتقويم الحكام المعتمدين في الاتحاد العراقي

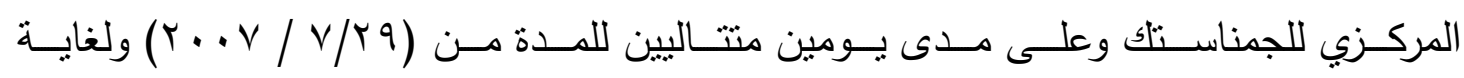

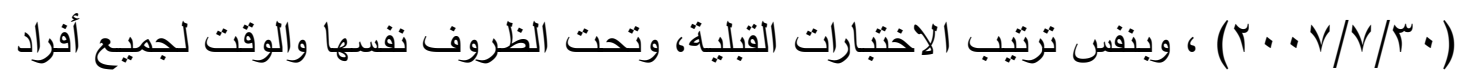
عينة البحث. ب- ب الوسائل الإحصائية

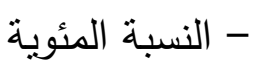

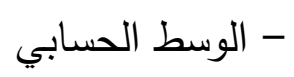

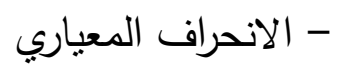
- معامل الارتباط البسيط (بيرسون) - اختبار (ت) للعينات المرتبطة

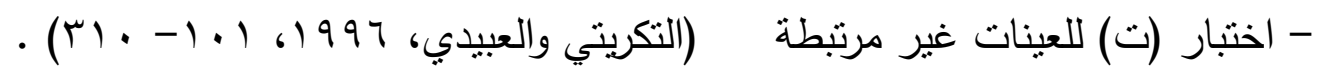
تم اسـتخدام جميـع العطليـات الإحصائية بوسـاطة الحاسـوب الآلـي وباسـتخدام نظسام $\cdot(\mathrm{SPSS})$

؛ - ع عرض النتائج وتحليلها ومناقشتها ع - 1 عرض النتائج ؟ - 1 - 1 عرض وتحليل نتائج بعض المنطلبات الخاصة ومستوى الأداء المهاري في الحركات الأرضية بين الاختبارين القبلي والبعدي للمجموعتين التجريبية والضابطة 


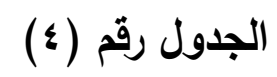

يبين المعالم الإحصائية وقيم (ت) بين الاختبارين القبلي والبعدي في بعض المتطلبات الخاصة ومستوى الأداء المهاري للمجموعة التجريبية

\begin{tabular}{|c|c|c|c|c|c|c|c|}
\hline \multirow{2}{*}{ النتيجة } & \multirow{2}{*}{ قليم (ت) } & \multicolumn{2}{|c|}{ الاختبار البعدي } & \multicolumn{2}{|c|}{ الاختبار القبلي } & \multirow{2}{*}{ القياس } & \multirow{2}{*}{ المتغيرات اللاحصائية } \\
\hline & & $\varepsilon^{ \pm}$ & س- & $\varepsilon^{ \pm}$ & س- & & \\
\hline معنوي & $r, o$ & • , r & $r, \varepsilon$ & • & 1,9 & درجة & بضض المتطلبات الخاصة \\
\hline معنوي & $r, v$ & •, $\leqslant$ & $I Y, Y V$ & $\cdot$, or & $M, \cdot V$ & درجة & مستوى الأداء المهاري \\
\hline
\end{tabular}

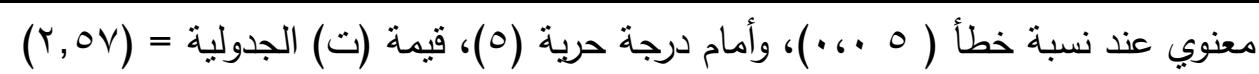
من الجدول رقم (ع) يتبين : إن قيمة (ت) المحسوبة والبالغة (r,0) بين الاختبارين

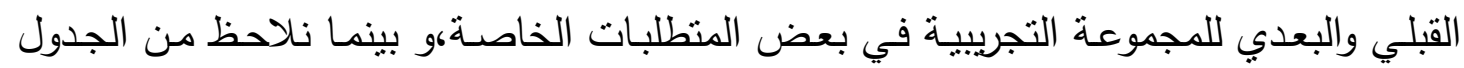

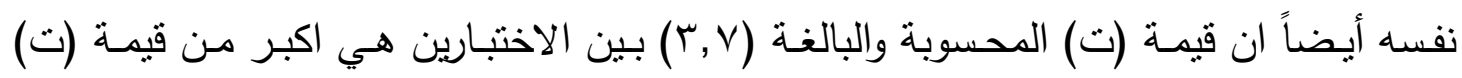

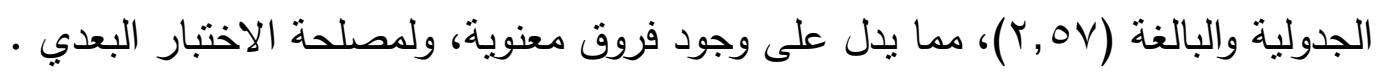

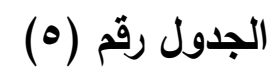

يبين المعالم الإحصائية وقيم (ت) بين الاختبارين القبلي والبعدي في بعض المتطلبات الخاصة ومستوى الأداء المهاري للمجموعة الضابطة الاعتابن

\begin{tabular}{|c|c|c|c|c|c|c|c|}
\hline \multirow{2}{*}{ النتيجة } & \multirow{2}{*}{ المحسية (ت) } & \multicolumn{2}{|c|}{ الاختبار البعدي } & \multicolumn{2}{|c|}{ الاختبار القبلي } & \multirow{2}{*}{ القياس } & \multirow{2}{*}{ المتغيرات الإحصائية } \\
\hline & & $\varepsilon^{ \pm}$ & س- س & $\varepsilon^{ \pm}$ & س- س & & \\
\hline غعنوي & $\cdot, \leq r \leq$ & $\cdot, Y V$ & l,v & $\cdot, \leq \varepsilon$ & 1,1 & درجة & 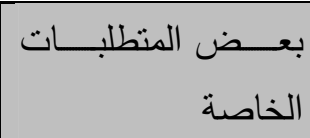 \\
\hline معنوي & $\cdot, V \leq T$ & $\cdot, Y V$ & 11,71 & $\cdot, r$ & $11, \varepsilon \wedge$ & درجة & مستوى الأداء المهاري \\
\hline
\end{tabular}

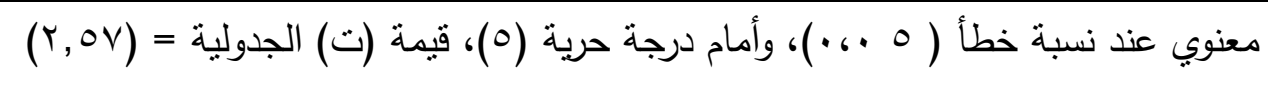

مـن خـلال الجدول رقم (ه) يتبين : ان قيمة (ت) المحسوبة والبالغـة (ع ب ع • ) بين الاختبارين القبلي والبعدي للمجموعة الضابطة في بعض المتطلبات الخاصـة بينما نلاحظ من

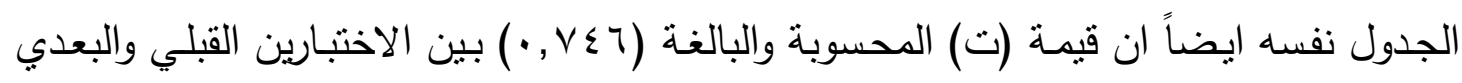

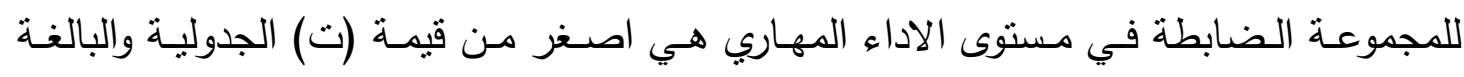

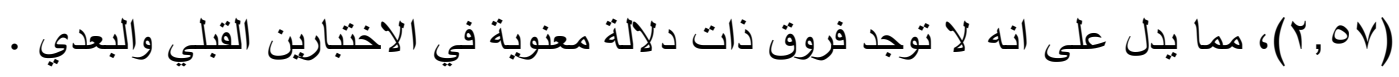


ع - 1 - r عرض وتحليل نتـائج الفـروق بـين المجمسوعتين التجريبيـة والـضابطة للمتطلبـات الخاصة ومستوى الأداء المهاري في الاختبار البعدي

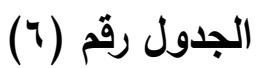

يبين المعاليم الإحصائية وقيم (ت) بين المجموعتين التجريبية والضابطة في الاختبار البعدي

\begin{tabular}{|c|c|c|c|c|c|c|c|}
\hline \multirow[t]{2}{*}{ النتيجة } & \multirow{2}{*}{ قيم (ت) } & \multicolumn{2}{|c|}{ الضابطة } & \multicolumn{2}{|c|}{ المجموعة التجريبية } & \multirow{2}{*}{ القياس } & \multirow{2}{*}{ المتغيرات /لالاحصائية } \\
\hline & & $\varepsilon^{ \pm}$ & س- & $\varepsilon^{ \pm}$ & س- & & \\
\hline معنوي & $\varepsilon, \varepsilon$ & $\cdot, Y V$ & $1, v$ & $\cdot, Y Y$ & $r, \varepsilon$ & درجة & بعض المنطلبات \\
\hline معنوي & $r, v$ & • & $M, T V$ & $\cdot$, Or & $I_{,}, \cdot V$ & درجة & مسنوى الأداء المهاري \\
\hline
\end{tabular}

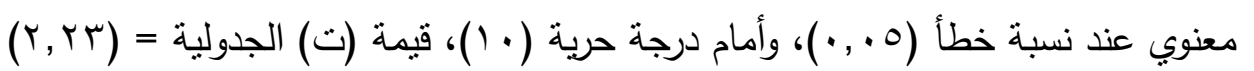

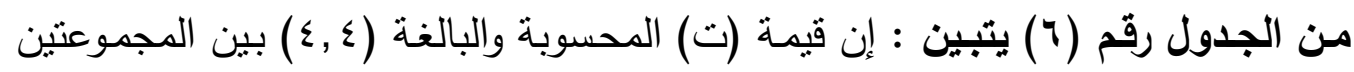
التجريبية والضابطة في بعض المنطلبات الخاصة بينما نلاحظ من الجدول نفسه ايضاً ان قيمة

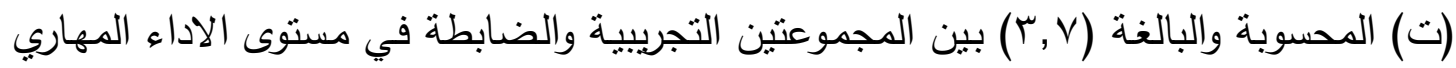

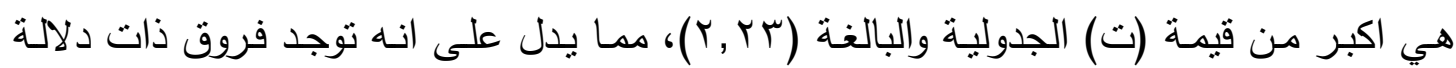
معنوية في الاختبار البعدي بين المجموعتين، ولمصلحة المجموعة التجريبية .

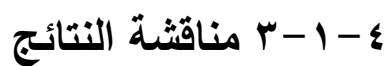
لقد اظهر الجدول رقم (؛) وجود فروق معنوية في الاختبارات القبلية والبعدية في مسنوى الأداء المهاري وبعض المتطلبات الخاصـة، ولمصلحة الاختبارات البعدية للمجموعة التجريبية التي استخدمت التدريب التكراري لتحسين المهارات الحركية، ويعزو الباحثان ذلك إلى التطور التهاه

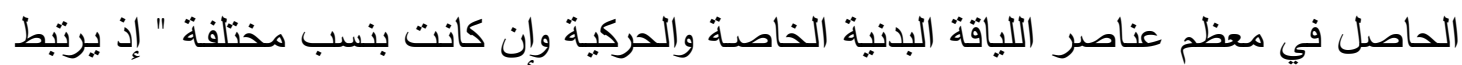

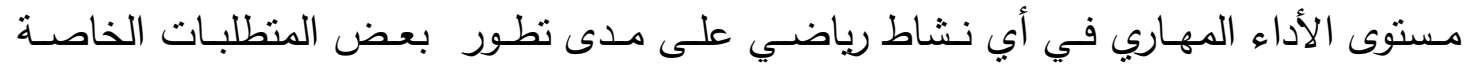

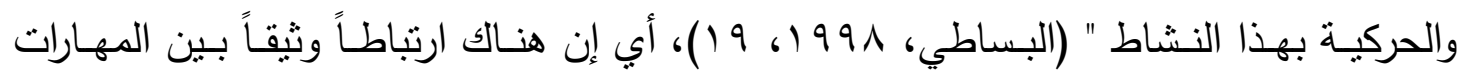

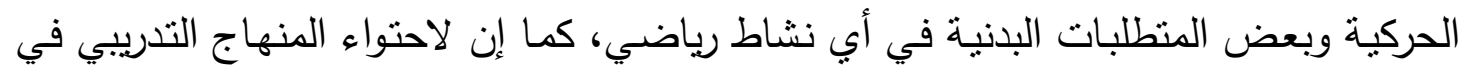

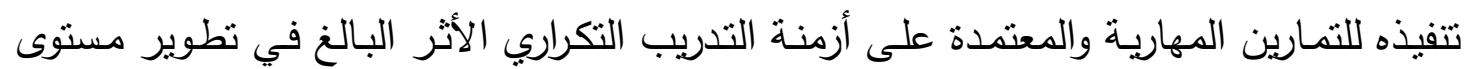

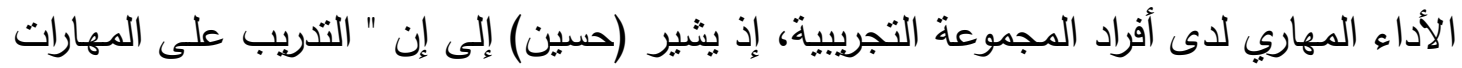

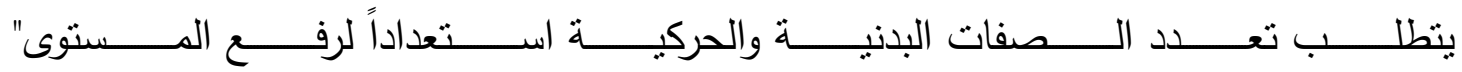

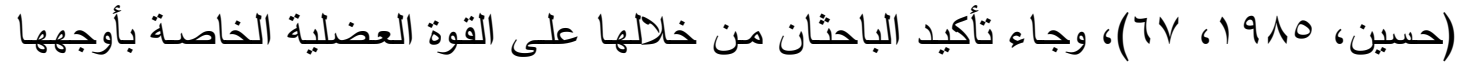

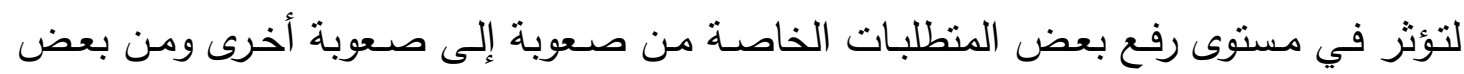

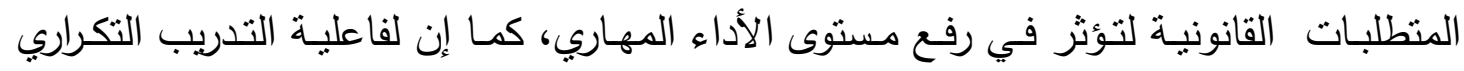


باستخدام المهارات الحركية الأثر الواضح ليس فقط في عناصر اللياقة البدنية الخاصة،بل في

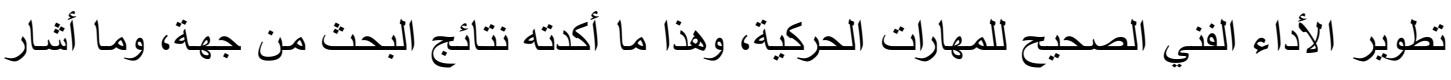

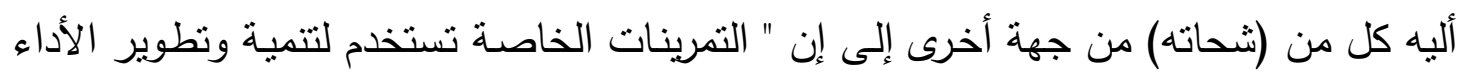

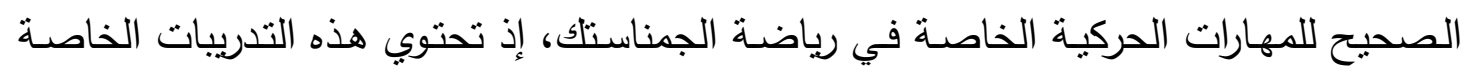

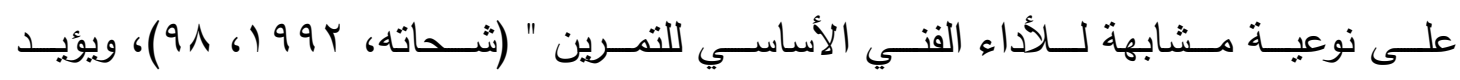
( Buhelerle and Werrner , 1984 )، هذا القول "بأنه يجب إن تتدمج تمرينات القوة

الخاصة مع المهارة في رياضة الجمناستك " (Buhelerle and werrner 1984 , 35 ) .

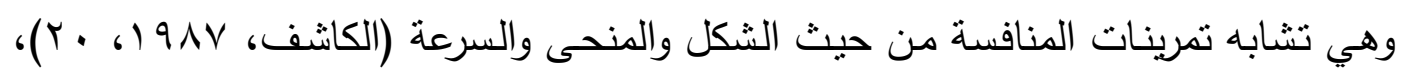
فضلاً عن عملية التكرار في طريقة التدريب المستخدمة التي أدت إلى تحسين الأداء الصحيح

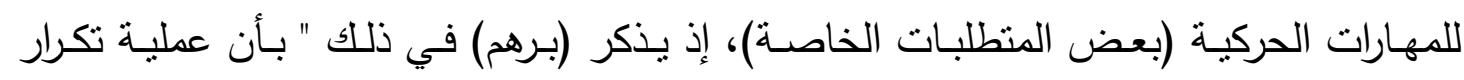

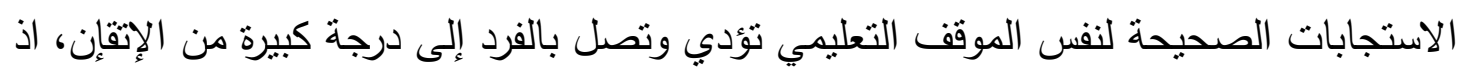
من خلال طريقة التكرار للموقف التعليمي واستجابته الصحيحة يتم التخلص من الأخطاء المرافقة

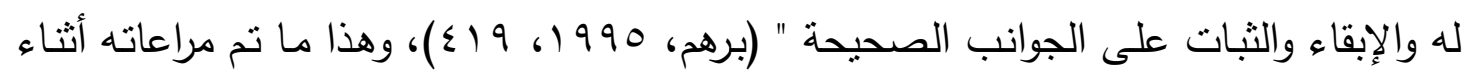

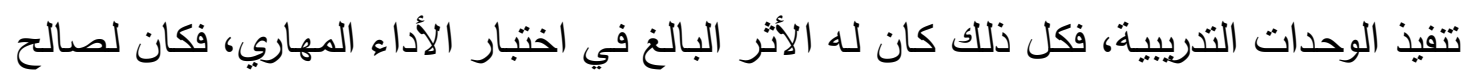

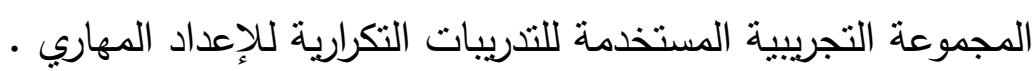

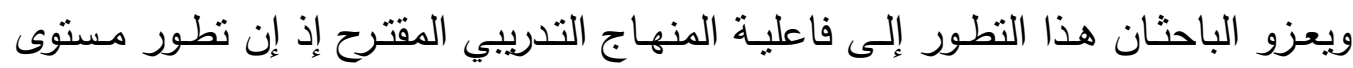

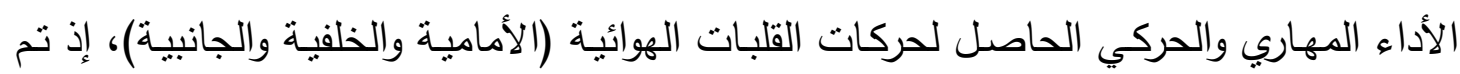

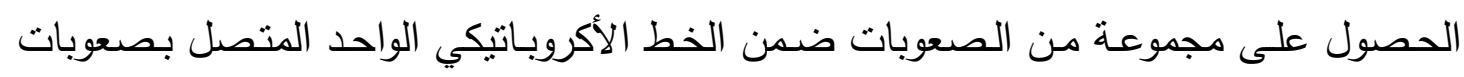

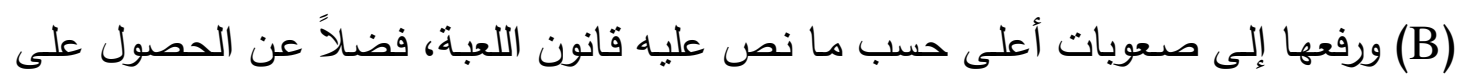

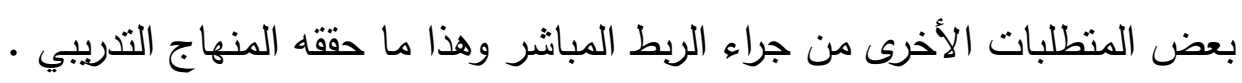

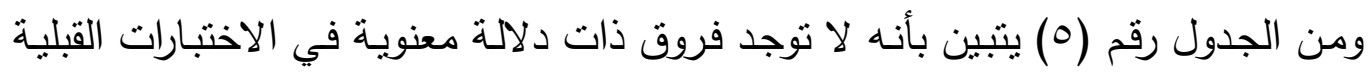

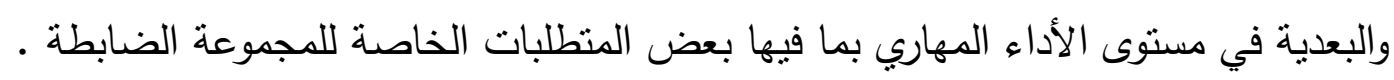
ويعزو الباحثان ذلك إلى ضعف طريقة التدريب التي أعدها المدرب والتي تميزت بعشوائية

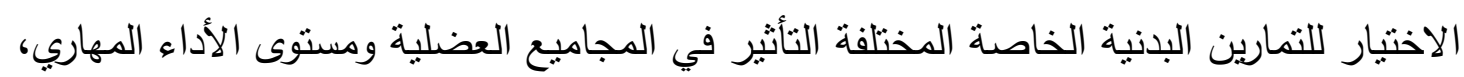

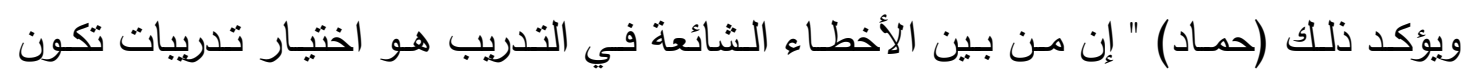

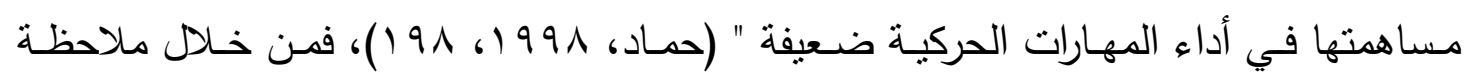

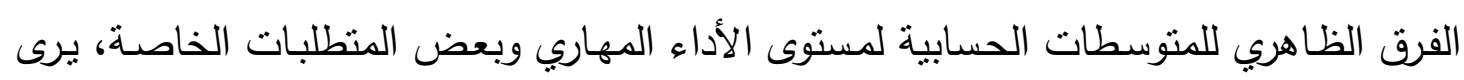

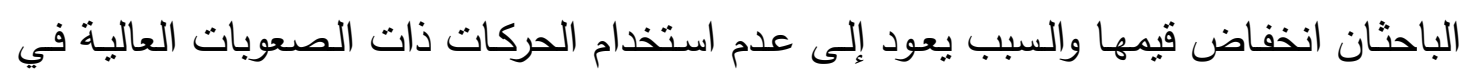

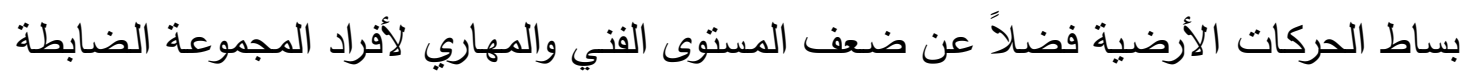
في الاختبار البعدي - مياك 


\section{في ضوء النتائج ومناقشتها استتنج الباحثان مايأتي:}

- احدث المنهاج التدريبي المقترح المستخدم من قبل المجموعة التجريبيـة في معظم متغيرات المتطلبات الخاصة ومستوى الأداء المهاري في الحركات الأرضية مقارنة بالمجموعة الضابطة

- لم يحرز المنهاج التقليدي الذي استخدمته المجموعة الضابطة أي تقدم في المنطلبات الخاصة قيد البحث لبساط الحركات الأرضية ومستوى الأداء المهاري في الحركات الأرضية.

•- r- r التوصيات

- استخدام المنهاج التدريبي المقترح في تطوير بعض المتطلبات الخاصة في الحركات الأرضية، فضلاً عن مستوى الأداء المهاري.

- الاهتمام بتدريب بعض المتطلبات الخاصة بوصفه النواة الحقيقية لكافة الحركات على بساط الحركات الأرضية.

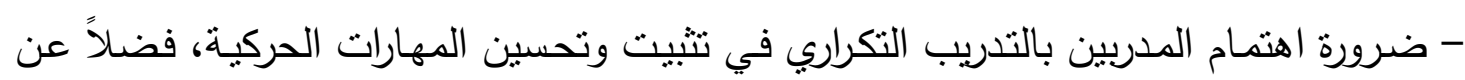
تتمية مستوى الأداء المهاري لدى لاعبي الجمناستك.

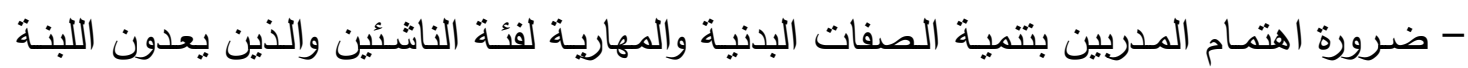
الأولى لعملية التدريب.

المصادر العربية والاجنبية لإنية

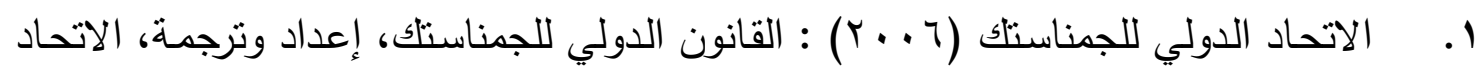

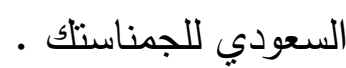

r. برهم، عبد المنعم سليمان(1990) : موسوعة الجمباز العصرية، طا، دار الفكر للطباعة

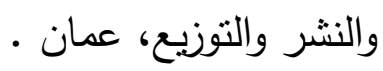

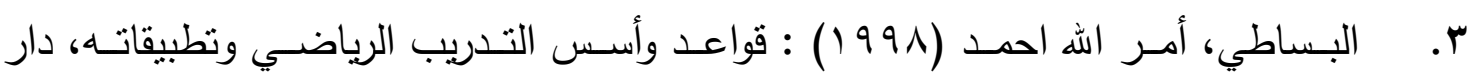

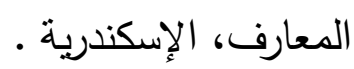

؛. التكريتي، وديع ياسين، والعبيدي، حسن محمد عبد (997 (19) : التطبيقات الإحصائية في

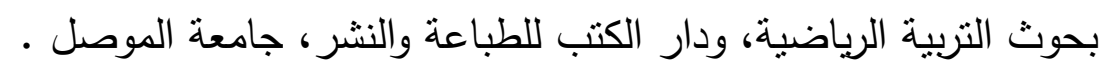

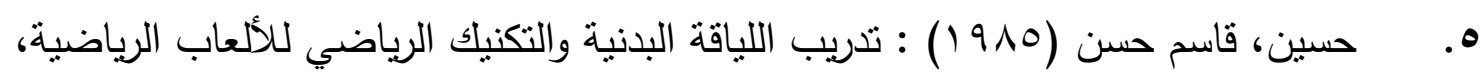
دار الكتب للطباعة والنشر ، جامعة الموصل . 
7. حمـاد، مفتي إبراهيم ( (1991) : التـدريب الرياضـي الحديث، طا، دار الفكر العربي

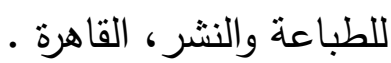

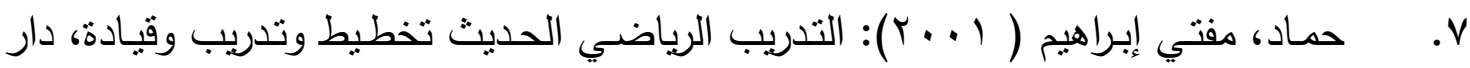
الفكر العبي للطباعة والنشر، القاهرة .

1. شحاتة، محمد ابراهيم (ب999 (1) : دليل الجمباز الحديث، دار المعارف، الإسكندرية.

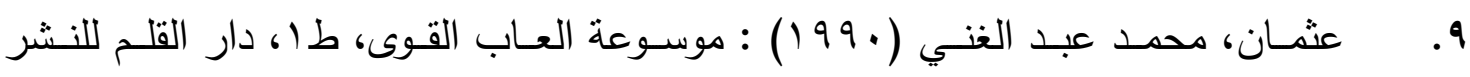
والتوزيع، مطبعة فيصل الكويت . • 1 . علاوي، محمد حسن وراتب، أسامة كامل (999 19) : البحث العلمي في التربية الرياضية وعلم النفس الرياضي، دار الفكر العربي، القاهرة . 11 . علي، عادل عبد البصير (991 (19) : النظريات والأسس العلمية لتدريب الجمناستك، دار

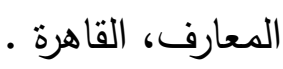
r 1. علي، مصطفى كامل احمد (919 ()): تأثثر برنامج تدريبي مقترح على مستوى تعلم وأداء

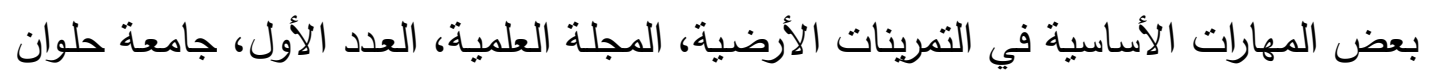

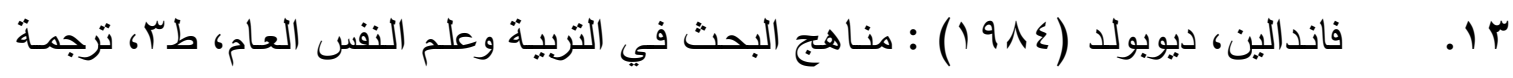
محمد نبيل نوفل واخرون، مكتبة ألا نجلو المصرية، القاهرة .

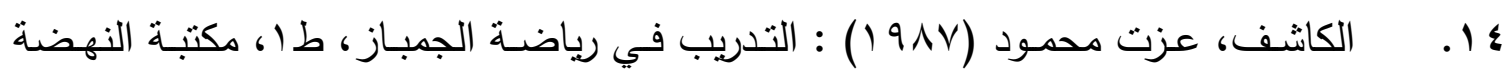

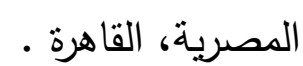
10. مصطفى، عـلاء الدين حامـ (999 (19) : ت تأثير تتميـة القوة العضلية النسبية والمرونـة لمفاصل كل من الذراعين والرجلين والعمود الفقري على مستوى أداء سلسلة اكروباتيكية خلفية على بساط الحركات الارضية في الجمباز ، مجلة اسيوط، للعلوم وفنون التربية الرياضية،

16- Buhrle.M. and Werrner. E. (1984) : "The musclehyperophy trining of the body builder ", Leistungs sport .

\section{ملحق (1)}

\section{نماذج من الوحدات التدريبية}

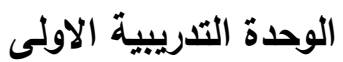

\begin{tabular}{|c|c|c|c|c|c|c|c|c|}
\hline التجرية & تمرين والخر & زمع الراحة العل & التركارات بين & التكرارات & زلتمرين & تصنيف & التمارين المستخدمة & ت \\
\hline
\end{tabular}




\begin{tabular}{|c|c|c|c|c|c|c|c|c|}
\hline \multirow{7}{*}{$\stackrel{L}{m}$} & & $0,1$. & و ث ثا & $\varepsilon$ & •ا & $\mathrm{C}$ & الارتتكــاز بزاوبـــة حــادة والـرجلين & .1 \\
\hline & I & & & & & & & \\
\hline & & $\wedge, \Gamma$. & • 10 ثا & $\varepsilon$ & 10 ثا & D & 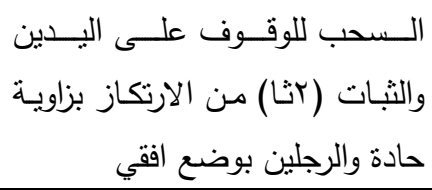 &.$r$ \\
\hline & $د r$ & & & & & & & \\
\hline & & $0,1$. & . & $\varepsilon$ & •ا ثا & $\mathrm{C}$ & قفـزة يـدين اماميـة مـع دورة هوائيـة &.$r$ \\
\hline & T & & & & & & & \\
\hline & & $0,1$. & ڤ & $\varepsilon$ & •ا ثا & $\mathrm{C}$ & دورة هوائيــــة امامييــــة مدـــــودة &.$\varepsilon$ \\
\hline
\end{tabular}

الوحدة التريبية الثالثة عثر

\begin{tabular}{|c|c|c|c|c|c|c|c|c|}
\hline زمن التجربة & تمرين واخة بين & زمن العمل & الراحة بين & عدد & زمن التمرين & تصنيف & التمارين المستخدمة & ت ت \\
\hline
\end{tabular}




\begin{tabular}{|c|c|c|c|c|c|c|c|c|}
\hline \multirow{7}{*}{$\begin{array}{l}2 \\
1 \\
\vdots \\
\vdots\end{array}$} & & $\Lambda, \Gamma$. & ا & $\varepsilon$ & 10 & $\mathrm{D}$ & 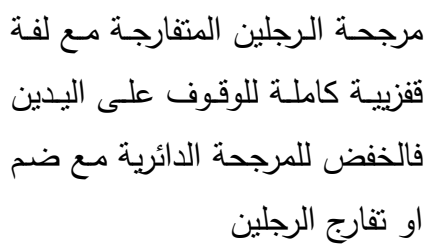 & .1 \\
\hline & r & & & & & & & \\
\hline & & $11, \wedge$. & 9 . & $\wedge$ & . & B & هوائية خلفية سريعة (تامبو) &.$r$ \\
\hline & L & & & & & & & \\
\hline & & 0,1 . & 9 . & $\varepsilon$ & ا & B & هوائية امامية خلفة ع نـصف لفـة مـع قلبـة & r \\
\hline & r & & & & & & & \\
\hline & & $0,1$. & 9 . & $\varepsilon$ & . & B & هوائية جانبية ممدودة &.$\varepsilon$ \\
\hline
\end{tabular}

الوحدة التدريبية الرابعة والعشرين

\begin{tabular}{|c|c|c|c|c|c|c|c|c|}
\hline التجرية & تمرين واخر بين & زمن العمل & التكرارة بين & التكرارات & 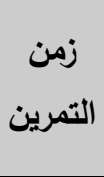 & تصنيف & التمارين المستخدمة & ت \\
\hline \multirow{7}{*}{$\stackrel{\circ}{a}$} & & $11, \wedge$. & q. & $\wedge$ & ا. & B & وثائبة امامية خلفيـة مـع نـصف لفــة لاداء & .1 \\
\hline & د & & & & & & & \\
\hline & & $\Lambda, r$. & إ & $\varepsilon$ & ا & $\mathrm{C}$ & وثوبــة خلفيـة مـع نـصف لفــة لاداء & .4 \\
\hline & $د r$ & & & & & & & \\
\hline & & 0,1 . & ا & $\varepsilon$ & . & B & هوائية جانبية ممدودة & r \\
\hline & د & & & & & & & \\
\hline & & $\Lambda, r$. & إ ثا & $\varepsilon$ & الثا & $\mathrm{C}$ & هو هوائية جانبية متفارجة دورة ونصف للفة للاحرجة الامامية &.$\varepsilon$ \\
\hline
\end{tabular}

